\title{
パーライト中のVC析出を利用した 非調質鋼の高強度化機構
}

\author{
大藤 善弘*・鳥塚 史郎 $* 2 \cdot$ 花村 年裕 $* 2$ \\ Mechanism of Strengthening by Vanadium Carbide Precipitation in Pearlite in Microalloyed Steels \\ Yoshihiro DAITOH, Shiro TORIZUKa and Toshihiro HANAMURA
}

Synopsis : In microalloyed steel, industrial candidate for application to parts of automobiles, we investigated strengthening mechanism by vanadium carbide (VC) precipitation in the pearlite. The specimens, containing $0.1-0.65 \%$ carbon $(\mathrm{C})$ and $0-0.4 \%$ vanadium $(\mathrm{V})$, were quenched from 1200 to $650-550^{\circ} \mathrm{C}$ and kept at this temperature. The more $\mathrm{V}$ and the lower transformation temperature, the higher strength can be obtained. The maximum $0.2 \%$ proof strength is determined to be $1450 \mathrm{MPa}$ for $0.65 \% \mathrm{C}-0.4 \% \mathrm{~V}$ steel and $1200 \mathrm{MPa}$ for $0.65 \% \mathrm{C}-0.2 \% \mathrm{~V}$ steel. $\mathrm{VC}$ is found to precipitate at interphase boundaries between the austenite and the ferrite in the pearlite. When the transformation temperature is lowered, the VC size becomes finer and the precipitation density increases. These results suggest that the strengthening mechanism by VC is the Orowan-type. The amount of precipitation strengthening by VC was calculated by Ashby-Orowan equation. Both the calculated and the experimental results were determined to have good correlation. Strengthening mechanism by VC and that by pearlite lamellar would be competitive, however the amount of precipitation strengthening by $\mathrm{VC}$ in pearlite was close to that in ferrite.

Key words : microalloyed steel; vanadium carbide; interphase boundary precipitation; strengthening mechanism.

\section{1. 緒言}

自動車のエンジンや足回りに用いられる鍛造部品には， コスト削減の観点から熱間鍛造後の焼入れ・焼戻しを行わ ない非調質鋼が広く用いられている11。また燃費向上を図 るために部品の軽量化が求められており，そのため部品の 高強度化がますます求められている。

従来からフェライト・パーライト系の非調質鋼にバナジ ウム $(\mathrm{V})$ を添加すると，熱間鍛造部品が高強度化すること が知られている2,3)。そのため, クランク，コンロッドなど の自動車部品用の非調質鋼にはVV添加鋼がよく用いられて おり，0.2\%を超えるVを添加した部品が実用化されてい る)。また $0.2 \%$ 耐力 (以降, YS と表記) が $1000 \mathrm{MPa}$ 程度 のデータも報告されている5)。そのため，さらなる部品の 軽量化のためには, YSが $1000 \mathrm{MPa}$ を回る強度が必要で ある。またVは高価な元素であるため, なるべく少ないV 量で高い強度を出すことも求められている。

これらの課題を実現するためには，V添加による高強度 化機構を理解することが重要である。V添加によって高強 度化するのは, V炭化物 (VC)がオーステナイトからフェ ライト変態, およびパーライト変態するときに, オーステ
ナイトとフェライトとの相界面で微細な VCが析出するた めであることが知られている6)。

オーステナイトからフェライト変態するときの, $\mathrm{VC} の$ 相界面析出については, VCの形状や析出機構が研究され

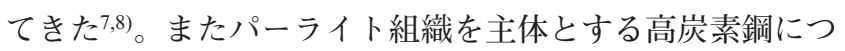
いても研究が行われ, 強度などの機械的性質だけでなく, 相界面析出した VCのシート間隔や相界面の成長形態など について報告されている7,99。しかし，VCの粒径や個数密 度の定量化は，これまであまり行われてきていないため， VCの析出強化機構について十分には理解されていない。

以上を踏まえ, 本研究の目的は, $\mathrm{V}$ 添加鋼を用いて, 焼 入れ・焼戻しを行うことなくYS $1000 \mathrm{MPa}$ 上回る強度を 得ること，またそれをなるべく少ない $\mathrm{V}$ 量で得ることとし， そのための化学成分と熱处理条件について調査した。また 高強度化の原因を解明するため, 析出した VCの粒径, 個 数密度を定量化し, ポリゴナルフェライト中, およびパー ライト中での VCによる強化量と強化機構について考察し た。

平成23年3月16日受付 平成23年 5 月 18 日受理 (Received on Mar. 16, 2011; Accepted on May. 18, 2011)

* （株）住友金属小倉, 鉄鋼材料の革新的高強度 - 高機能化基盤研究開発研究体 (Sumitomo Metals (Kokura), Ltd., 1 Konomimachi Kokurakita-ku Kitakyushu 802-8686, "Fundamental Studies on Technologies for Steel Materials with Enhanced Strength and Functions," Consortium of JRCM)

* 2 独立行政法人 物質・材料研究機構, 鉄鋼材料の革新的高強度・高機能化基盤研究開発研究体 (National Institute for Materials Science, “Fundamental Studies on Technologies for Steel Materials with Enhanced Strength and Functions," Consortium of JRCM) 
Table 1. Chemical composition of steels (mass $\%$ ).

\begin{tabular}{|c|c|c|c|c|c|c|c|c|}
\hline Mark & $\mathrm{C}$ & $\mathrm{Si}$ & $\mathrm{Mn}$ & $\mathrm{S}$ & $\mathrm{Cr}$ & $\mathrm{Al}$ & $\mathrm{V}$ & $\mathrm{N}$ \\
\hline \hline 10C-0V & $\mathbf{0 . 0 8}$ & 0.66 & 1.13 & 0.015 & 0.40 & 0.026 & $\mathbf{0 . 0 0}$ & 0.0038 \\
\hline 10C-2V & $\mathbf{0 . 0 8}$ & 0.64 & 1.13 & 0.015 & 0.40 & 0.028 & $\mathbf{0 . 1 9}$ & 0.0045 \\
\hline 10C-4V & $\mathbf{0 . 0 9}$ & 0.65 & 1.14 & 0.015 & 0.42 & 0.029 & $\mathbf{0 . 4 1}$ & 0.0055 \\
\hline 40C-0V & $\mathbf{0 . 3 8}$ & 0.66 & 1.14 & 0.014 & 0.41 & 0.033 & $\mathbf{0 . 0 0}$ & 0.0040 \\
\hline 40C-4V & $\mathbf{0 . 3 9}$ & 0.66 & 1.16 & 0.014 & 0.42 & 0.034 & $\mathbf{0 . 4 1}$ & 0.0051 \\
\hline 65C-0V & $\mathbf{0 . 6 4}$ & 0.65 & 1.14 & 0.016 & 0.41 & 0.028 & $\mathbf{0 . 0 0}$ & 0.0032 \\
\hline 65C-2V & $\mathbf{0 . 6 4}$ & 0.65 & 1.14 & 0.014 & 0.41 & 0.034 & $\mathbf{0 . 2 0}$ & 0.0045 \\
\hline $65 \mathrm{C}-4 \mathrm{~V}$ & $\mathbf{0 . 6 5}$ & 0.65 & 1.17 & 0.016 & 0.43 & 0.030 & $\mathbf{0 . 4 1}$ & 0.0040 \\
\hline
\end{tabular}

\section{2. 実験方法}

化学成分については $\mathrm{C}$ 量, および $\mathrm{V}$ 量の影響を明確化す るために, Table 1 に示す組成の鋼を溶解した。供試材は, 真空溶解により $50 \mathrm{~kg}$ インゴットに鋳造後, 熱間鍛造に よって $625 \mathrm{~mm}$ の棒鋼にした後, 焼準を施した。その焼準 材から機械加工によって， $\phi 10 \mathrm{~mm} \times 130 \mathrm{mmL}$ と $\phi 3 \mathrm{~mm} \times$ $10 \mathrm{mmL}$ の試験片を作製した。熱処理は， $\phi 10 \mathrm{~mm}$ の試験片 については, 熱間加工シミュレーター（富士電波工機製 Thermecmastor-Z) で， $\phi 3 \mathrm{~mm}$ の試験片については，熱処 理シミュレーター（富士電波工機製 Formastor-EDP）を用 いた。熱処理条件は, 真空中で室温から $1200^{\circ} \mathrm{C}$ に 60 秒に 加熱後, 窒素ガスを用いて $10^{\circ} \mathrm{C} /$ 秒または $20^{\circ} \mathrm{C} /$ 秒の冷 却速度で $650 \sim 550^{\circ} \mathrm{C}$ まで冷却した後, その温度で 600〜1800秒間保持し，その後，室温まで放冷とした。こ の冷却中に変態が開始しないことを確認している。なお保 持時間については, 変態が完了する時間の 2 倍以内を目安 とした。この試験片を組織観察, 引張試験の各調査に供し た。引張試験の形状は, 平行部の直径を $3.2 \mathrm{~mm}$, 長さを $18 \mathrm{~mm}$ とした。

組織観察には光学顕微鏡, 走査型電子顕微鏡 (SEM) およ び透過型電子顕微鏡 $(\mathrm{TEM})$ を用いた。光学顕微鏡, およ びSEM観察の試料はナイタールで腐食したものを，TEM 観察の試料には機械研磨後, 電界研磨によって薄片化した ものを用いた。

\section{3. 実験結果}

Fig. 1 に $650^{\circ} \mathrm{C}, 600^{\circ} \mathrm{C}, 550^{\circ} \mathrm{C}$ のれぞれの温度で等温保 持した $\mathrm{C}$ 量の異なる $0.4 \% \mathrm{~V}$ 鋼の光学顕微鏡写真を示した。 $650^{\circ} \mathrm{C}$ 保持では， $10 \mathrm{C}-4 \mathrm{~V}$ 鋼はほぼポリゴナルフェライト 単相の組織, $40 \mathrm{C}-4 \mathrm{~V}$ 鋼は少量の初析フェライトがある パーライト主体の組織, $65 \mathrm{C}-4 \mathrm{~V}$ 鋼はほぼパーライト単相 の組織となった。 $10 \mathrm{C}-4 \mathrm{~V}$ 鋼は, $650^{\circ} \mathrm{C}$ 保持ではポリゴナ ルフェライト組織が主体であるが, 保持温度が $600^{\circ} \mathrm{C}$, $550^{\circ} \mathrm{C}$ と下がるに従って, ウィドマンステッテンフェライ トやべイナイト組織が混在した。 $40 \mathrm{C}-4 \mathrm{~V}$ 鋼と $65 \mathrm{C}-4 \mathrm{~V}$ 鋼 の $600^{\circ} \mathrm{C}$ 保持材, $550^{\circ} \mathrm{C}$ 保持材の組織は, 光学顕微鏡によ る観察では， $650^{\circ} \mathrm{C}$ 保持材と大きな差はなく，パーライト 主体の組織に見えるが, 上部べイナイトとの区別は難しい

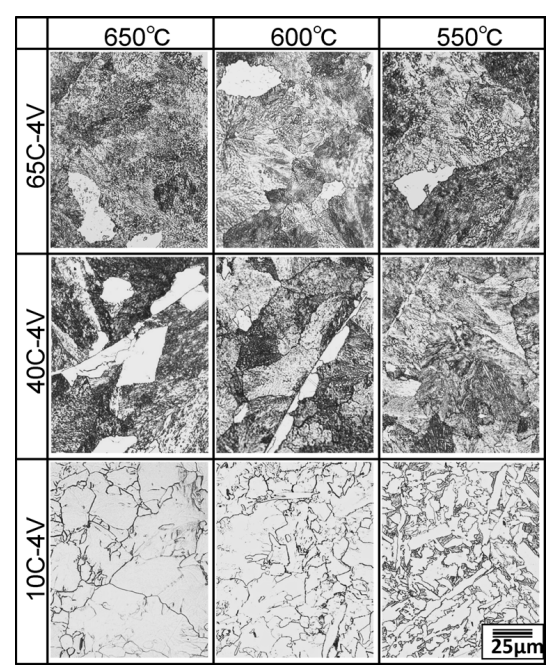

Fig. 1. Optical micrographs of $0.4 \%$ V-added steels holding at 650,600 and $550^{\circ} \mathrm{C}$.

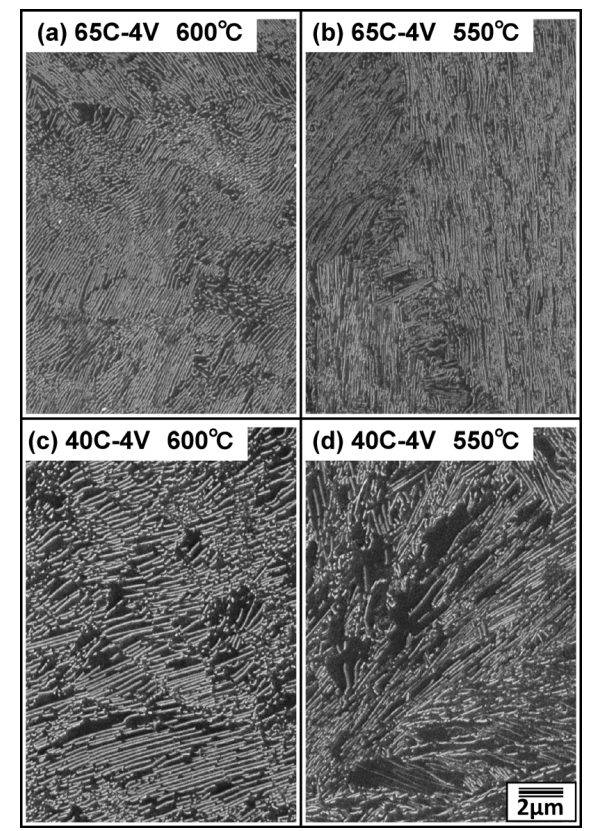

Fig. 2. SEM micrographs of $0.4 \% \mathrm{~V}$-added steels holding at 600 and $550^{\circ} \mathrm{C}$.

ため，SEMによる観察も行った。Fig. 2に示すように， $65 \mathrm{C}-4 \mathrm{~V}$ 鋼は $550^{\circ} \mathrm{C}$ 保持でもパーライト組織であったが， $40 \mathrm{C}-4 \mathrm{~V}$ 鋼は, $600^{\circ} \mathrm{C}$ 保持ではパーライト組織であるが, $550^{\circ} \mathrm{C}$ 保持では上部べイナイトが混在したパーライト組織 になっていた。

Fig. 3 に $0.65 \% \mathrm{C}$ でV量，および等温保持温度を変化さ せたときの引張試験におけるYSを示した。Fig. 3 からわか るように, $\mathrm{V}$ 量の増加，および等温保持温度の低温化に 伴って YS は増加した。また $65 \mathrm{C}-4 \mathrm{~V}$ 鋼では最大で $\mathrm{YS}$ $1450 \mathrm{MPa}$ が，65C-2V鋼では $1200 \mathrm{MPa}$ が得られた。次に Fig. 4 に $0.4 \%$ C鋼での結果を示した。 $0.65 \%$ Cの場合には, $650^{\circ} \mathrm{C}$ から $550^{\circ} \mathrm{C}$ まで, 保持温度が下がるに従って YS が増 加するのに対し， $40 \mathrm{C}-4 \mathrm{~V}$ 鋼では $600^{\circ} \mathrm{C}$ 以下で $\mathrm{YS}$ は増加し 


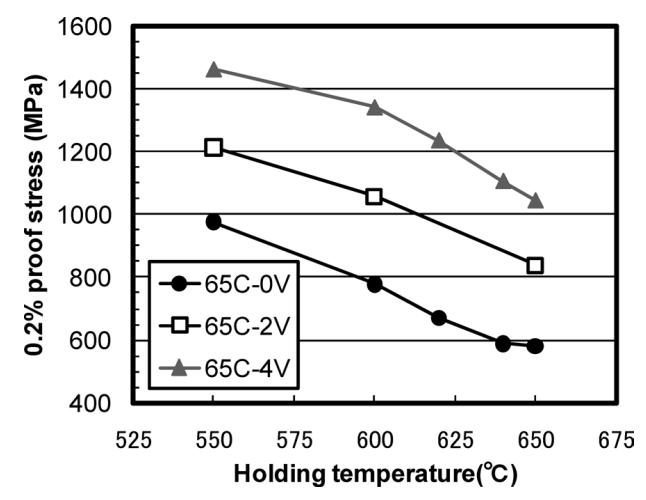

Fig. 3. $0.2 \%$ proof stress of $0.65 \% \mathrm{C}$ steels holding at various temperatures.

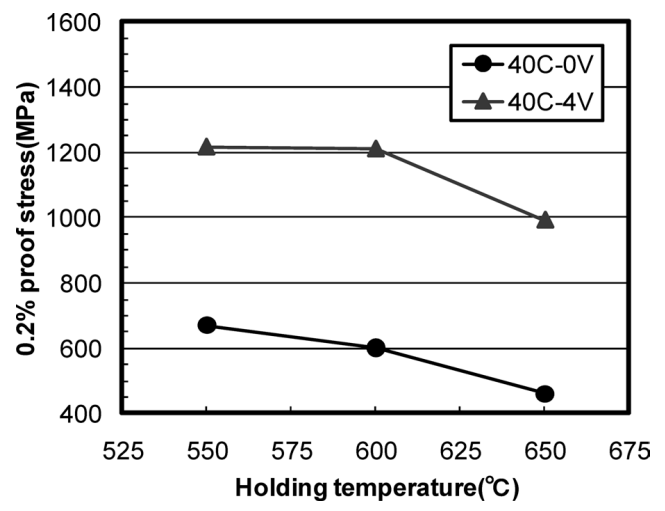

Fig. 4. $0.2 \%$ proof stress of $0.4 \% \mathrm{C}$ steels holding at various temperatures.

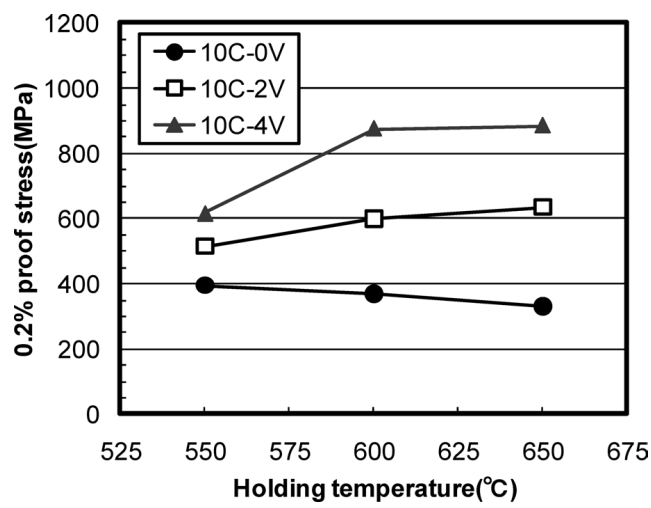

Fig. 5. $0.2 \%$ proof stress of $0.1 \% \mathrm{C}$ steels holding at various temperatures.

なくなった。さらに Fig. 5に示すように，0.1\% Cの場合， $\mathrm{V}$ 非添加鋼である $10 \mathrm{C}-0 \mathrm{~V}$ 鋼では $650^{\circ} \mathrm{C}$ から $550^{\circ} \mathrm{C}$ まで, 保持温度が下がるに従ってYSが増加したのに対し，

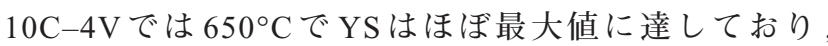

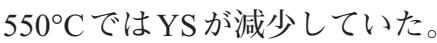

Fig. 3〜5に示した結果から， $0.4 \% \mathrm{~V}$ 鋼の結果のみを取り 出して, Fig. 6に示した。Fig. 6からわかるように $650^{\circ} \mathrm{C}$ 保 持では C 量の違いによる YS 差は100 150 MPa とあまり大 きくないが，低温になるに従って差が大きくなり，550 $\mathrm{C}$ 保持では $10 \mathrm{C}-4 \mathrm{~V}$ 鋼と $65 \mathrm{C}-4 \mathrm{~V}$ 鋼で $800 \mathrm{MPa}$ を上回る差に

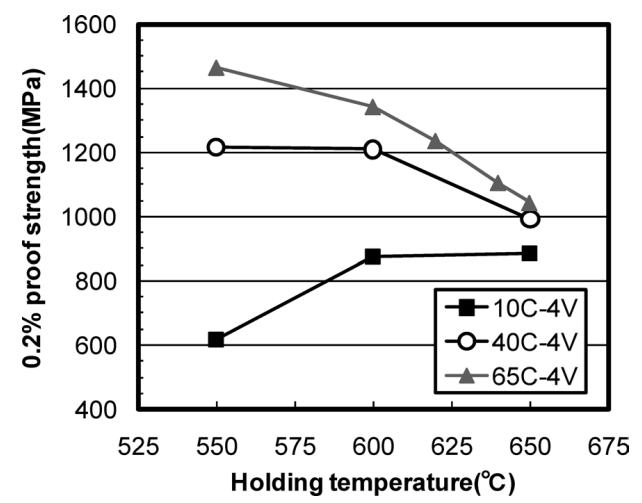

Fig. $6.0 .2 \%$ proof stress of $0.4 \% \mathrm{~V}$-added steels holding at various temperatures.

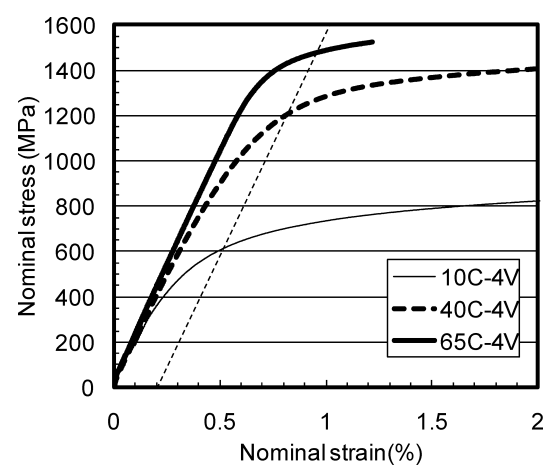

Fig. 7. Stress-strain curve of $0.4 \%$ V-added steels holding at $550^{\circ} \mathrm{C}$

なっていた。このような結果になった原因を明らかにする ために, $0.4 \% \mathrm{~V}$ 鋼の $550^{\circ} \mathrm{C}$ 保持材を引張試験したときの応 力ーひずみ曲線を Fig. 7に示した。65C-4V鋼が $1200 \mathrm{MPa}$ を超える応力から降伏しているのに対し，40C-4V鋼と $10 \mathrm{C}-4 \mathrm{~V}$ 鋼は，YSよりも大幅に低い応力から降伏を開始し ていた。この結果は $40 \mathrm{C}-4 \mathrm{~V}$ 鋼と $10 \mathrm{C}-4 \mathrm{~V}$ 鋼の $550^{\circ} \mathrm{C}$ 保持 材中に軟質な相が混在していることを示唆している。

さらにVCによる析出強化量を同じ等温保持温度で熱処 理した V 非添加鋼と V 添加鋼の $0.2 \%$ 耐力差として求めた。 析出強化量を厳密に求めるためには, V添加によるパーラ イトラメラ間隔の変化などのマトリックス組織の強度変化 も考慮する必要があるが，等温保持温度 $650 \sim 550^{\circ} \mathrm{C}$ の範 囲では，V添加によるパーライトラメラ間隔の変化は小さ かったため, 今回はV添加によってマトリックス組織の強 度は変化しないと仮定した。Fig. 8は，その仮定のもとで の VCによる析出強化量と等温保持温度の関係を示した図 であり， $65 \mathrm{C}-4 \mathrm{~V}$ 鋼， $40 \mathrm{C}-4 \mathrm{~V}$ 鋼では析出強化量は $600^{\circ} \mathrm{C}$ 付 近で最大となり，550 600 MPaに達している。また 10C$4 \mathrm{~V}$ 鋼では $650^{\circ} \mathrm{C}$ 付近で最大となり, $650^{\circ} \mathrm{C}$ 保持同士で比較 すれば, 高C鋼よりも析出強化量は大きかったが, $550^{\circ} \mathrm{C}$ では大きく減少していた。

以上述べたように, 最大のYSが得られる温度域, およ びVCによる析出強化量が最大となる温度域が存在し，そ 


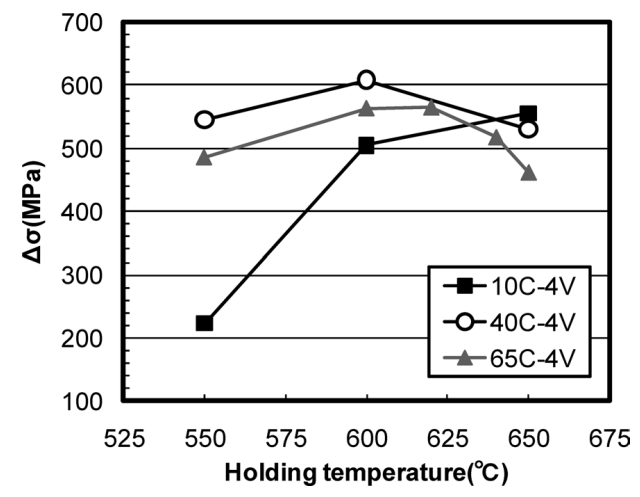

Fig. 8. Effect of holding temperature on $\Delta \sigma$, difference between $0 \% \mathrm{~V}$ and $0.4 \% \mathrm{~V}$-added steels in $0.2 \%$ proof stress.

れがC量によって異なった。Fig. 1 と Fig. 2に示した組織観 察の結果から， $40 \mathrm{C}-4 \mathrm{~V}$ 鋼の $550^{\circ} \mathrm{C}$ 保持では上部べイナイ ト， $10 \mathrm{C}-4 \mathrm{C}$ 鋼の $600^{\circ} \mathrm{C}, 550^{\circ} \mathrm{C}$ 保持ではウィドマンステッ テンフェライトやベイナイト組織が混在していた。 $650^{\circ} \mathrm{C}$ 保持材での組織であるパーライトやポリゴナルフェライト 中にはVCが析出して高強度化に寄与しているのに対し， 上部ベイナイトやウィドマンステッテンフェライト組織中 にはVCがあまり析出していないため，軟質である可能性 が高い。またC量の増加によって，VCが析出しないべイ ニテックな組織が生成し始める温度が低温側に移行するた めに, C量の増加によって YS, および析出強化量が最大 となる温度域が低温側に移行した。

以上のことから, $\mathrm{V}$ 添加鋼を有効に高強度化するために は，C量を増加することによってパーライト主体となる変 態温度範囲を低温に拡大し，その温度域で変態させるとよ いことがわかった。

\section{4. 考察}

Fig. 3〜8に示したように, YSは $\mathrm{C}$ 量, $\mathrm{V}$ 量, および等温 保持温度に大きく影響される。これにはVCの析出強化が 大きく寄与していると考えられるため，VC粒を定量化し， 析出強化機構について考察した。

さらに析出強化量を議論するためには，析出物である VCの大きさ，析出密度を定量化する必要があるため， TEM観察を行った。Fig. 9は 0.4\% V鋼をTEMで観察した ときの暗視野像であり, 写真中の白い粒子は, VCの回折 スポットを用いて結像させたものである。Fig. 9からわか るように，パーライト中のフェライトを観察している $65 \mathrm{C}-4 \mathrm{~V}$ 鋼同士で比較すると，等温保持温度が高くなるに 従い，VC粒は大きくなり，個数が減少していた。一方， $65 \mathrm{C}-4 \mathrm{~V}$ 鋼とポリゴナルフェライト中を観察している 10C-4V鋼を同じ保持温度で比較すると, Fig. 9に示した写 真では $10 \mathrm{C}-4 \mathrm{~V}$ 鋼のほうが VCの個数が多い。しかし，

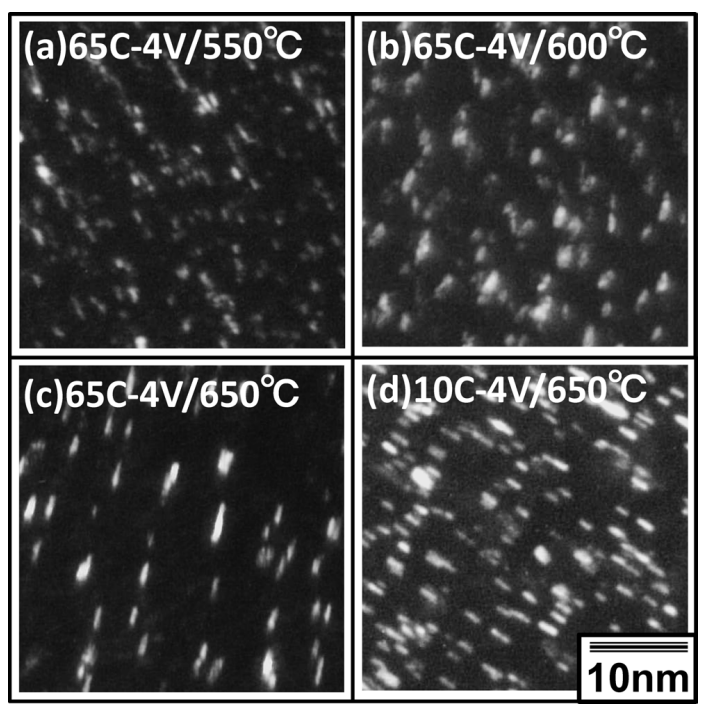

Fig. 9. Dark field TEM images of $0.4 \%$ V-added steels holding at various temperatures. (a)-(c) were observed at pearlite region. (d) was observed at polygonal ferrite region.

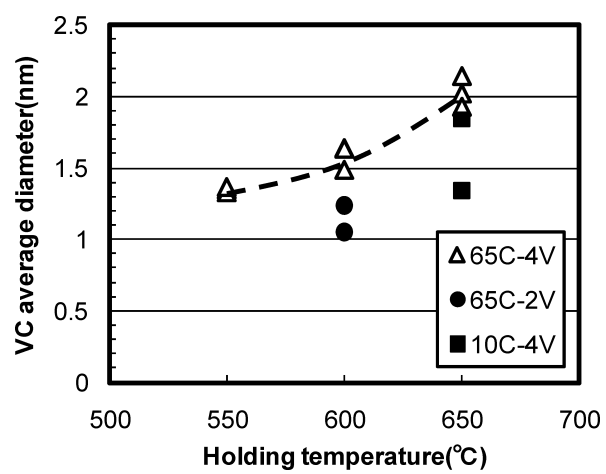

Fig. 10. VC average diameter of $0.65 \% \mathrm{C}$ steels holding at various temperatures.

10C-4V鋼では視野による個数の差が大きく，65C-4V鋼よ りも個数が少ない領域もあった。ここで, TEM写真から 析出密度を定量的に評価するためには，TEM試料の厚さ を求める必要があるため, 収束電子回折像を撮影して試料 厚さを求めた。なお試料厚さは試料によって異なるが， 40〜120 nmの範囲だった。各試料について, 各3視野を用 いて画像解析によって, $\mathrm{VC}$ の直径と個数を求め, 試料厚 さを考慮することで，個数密度を算出した。パーライト中 のフェライトを観察している $0.65 \% \mathrm{C}-\mathrm{V}$ 添加鋼についての 定量化した結果を Fig.10 と Fig.11に示した。

Fig.10はVCの平均直径であり，等温保持温度が低くな るに従って，平均直径は小さくなっていることがわかる。 な打図中の点線は， $65 \mathrm{C}-4 \mathrm{~V}$ 鋼について 3 視野の平均值を 結んだ線である。またV 含有量が少ないほうが，平均直径 が小さい傾向が認められた。ここではVCの直径を求める 際，VC各粒子の面積を求め, 形状を真円と仮定した。ま た $\mathrm{VC}$ の析出密度は, 等温保持温度が低くなるに従って, 大きくなる傾向があったが， $600^{\circ} \mathrm{C}$ 以下ではほほ飽和した。 


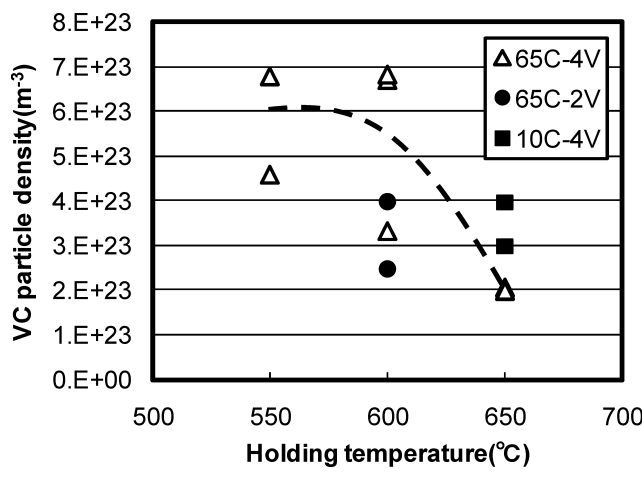

Fig. 11. VC particle density of $0.65 \% \mathrm{C}$ steels holding at various temperatures.

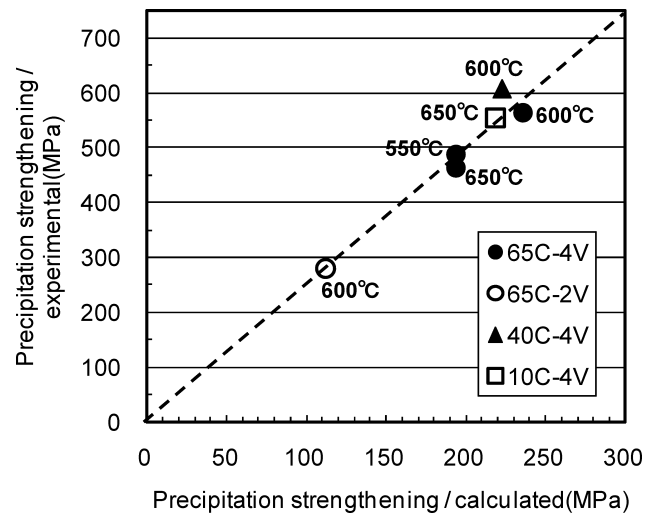

Fig. 12. Correlation between calculated and experimental precipitation strengthening by VC.

また $\mathrm{V}$ 量を $0.4 \%$ から $0.2 \%$ に低減すると, 析出密度もほぼ 半減した。一方, $10 \mathrm{C}-4 \mathrm{~V}$ 鋼については, ポリゴナルフェ ライト主体となる $650^{\circ} \mathrm{C}$ 保持材について, $\mathrm{VC}$ 粒の定量化 を行い, Fig. 10 と Fig. 11 中に示した。 $65 \mathrm{C}-4 \mathrm{~V}$ 鋼の $650^{\circ} \mathrm{C}$ 保 持材と比べると, 平均直径が小さく, 析出密度は大きかっ たが，その差はあまり大きくなかった。

以上のように求めた $\mathrm{VC}$ の平均直径と析出密度から, 式 (1)に示す Ashby-Orowanの式 ${ }^{10)}$ 用いて, 析出強化量を 算出した。な打, $M$ はテイラー因子 $(2.0), G$ は母相の剛性 率 $(83100 \mathrm{MPa}), \quad b$ はバーガースベクトル $(0.25 \mathrm{~nm}), L$ はす べり面上での粒子間隔（すべり面上に正方格子状に分布す ると仮定) , $x$ はすべり面上での粒子直径とした。

$$
\Delta \sigma=M \cdot 0.84(1.2 \cdot G \cdot b / 2 \pi \cdot L) \cdot \ln (x / 2 b)
$$

Fig.12 は式(1)から求めた析出強化量の計算值と, Fig. 8 に示した実験值を比較したものであり，絶対值では大きく 異なっていることがわかる。TEM観察結果から求めた, $\mathrm{VC}$ の平均直径, および析出密度から計算した $\mathrm{VC} の$ 体積

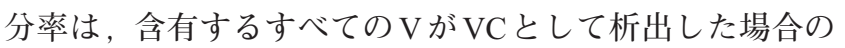
1/5程度だった。Vは, $\mathrm{VC}$ として析出しているだけでなく， フェライト中やセメンタイト中にも固溶していると考えら れるが，VCの溶解度積から考えると，TEM観察結果から 求めた VCの体積分率は少ない。したがって, 実験值と計

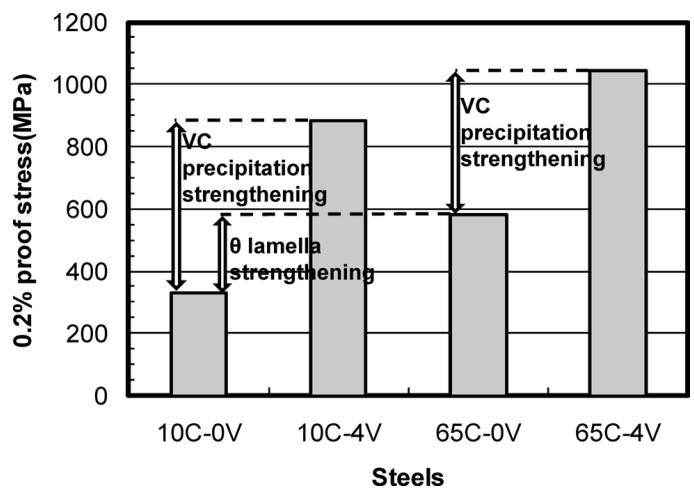

Fig. 13. Estimations of precipitation strengthening by $\mathrm{VC}$ and lamella strengthening by cementite from difference of $0.2 \%$ proof stress.

算值で絶対值が異なる原因としては，TEM観察において， $\mathrm{VC}$ 粒子の中でも特に微細なものが，暗視野で十分に結像 できなかったこと，回折条件の違いによる VC粒子の数え 落とし11)などにより，粒子間隔を過小評価した可能性が考 えられる。これらの過小評価の要因はすべての試料に共通 すると考えられること，打よび計算值と実験值の間には一 次の比例関係があり, Fig.12中に示した実験值／計算值 $=$ 2.5 の点線で, 非常によい相関関係を示したことから, 以 下の議論を進めた。

VCによる析出強化機構が Cutting 機構であれば，VCの 直径が小さくなる低い等温保持温度で, 析出強化量が減少 するはずであるが，そのような傾向は見られないことから， $\mathrm{VC}$ 粒の直径が 1 2 nmであっても Cutting機構ではなく, Orowan機構で析出強化に寄与していると考えられる。ま た等温保持温度が高くなるに従って，VC粒の個数密度は 減少するが，直径が大きくなるため，式(1)から求まる析 出強化量はあまり減少せず, 実測值の傾向と対応していた。 一方，V量が $0.4 \%$ から $0.2 \%$ になった場合, $\mathrm{VC}$ 粒の直径が あまり変わらず, 個数密度が減少するため, 析出強化量が 減少すると理解できた。

以上述べたように, $\mathrm{VC}$ の析出強化機構は Cutting機構で はなく, Orowan機構であること, および析出強化には個 数密度だけでなく粒子径の影響もあると推定されるため， 析出強化量の予測にはAshby-Orowan タイプの式が適して いることが明らかになった。

Fig.12では, VCによる析出強化量の計算値と実験值が よい相関関係を示したが，ポリゴナルフェライト中とパー ライト中の VCとで析出強化量は同じであるか検証する必 要がある。言い換えればパーライトラメラによる強化に $\mathrm{VC}$ の析出強化は単純に加算されるかを検討することとし た。そこで，アシキュラーフェライトやベイナイトが生成 しなかった $650^{\circ} \mathrm{C}$ 保持材で， $0.1 \% \mathrm{C}$ 鋼と $0.65 \% \mathrm{C}$ 鋼の $0.2 \%$ 耐力を比較した。Fig.13に示すように，10C-0V鋼と65C$0 \mathrm{~V}$ 鋼の差がパーライトラメラによる強化であり， $0 \% \mathrm{~V}$ 鋼 と $0.4 \% \mathrm{~V}$ 鋼の差が $\mathrm{VC}$ の析出強化量と見なすことができ 
る。Fig. 8 に示すように, $650^{\circ} \mathrm{C}$ 保持材では，パーライト 主体の組織となる $40 \mathrm{C}-4 \mathrm{~V}$ 鋼，打よび $65 \mathrm{C}-4 \mathrm{~V}$ 鋼の析出強 化量は，フェライト単相主体の組織となる $10 \mathrm{C}-4 \mathrm{~V}$ 鋼のよ りも，数 10 100 MPa小さかった。しかし，Fig.12に示し たように，析出した VCの大きさ，析出密度を考虑すると， ポリゴナルフェライト中とパーライト中の VCの析出強化 能は同等であると考えられる。

パーライトラメラによる強化機構については, まだ諸説 があるが， $0.2 \%$ 耐力とラメラ間隔の関係はラメラ間隔の $-1 / 2$ 乗 $^{12)}$ ，打よび -1 乗 $^{13)}$ で比較的よく整理できるが， $-1 / 2$ 乗の場合, ラメラ間隔が無限大での $0.2 \%$ 耐力が負に なるのに対し，-1乗では正の值をとることから，-1乗が 妥当との見解がある13)。ラメラによる強化量がー1乗で整 理されると考えれば，析出強化量は粒子間隔の -1 乗で整 理できることから，ラメラ強化と析出強化は同じ強化機構 である可能性が高い。今回の調査に用いた等温保持材での パーライトラメラ間隔は 100 200 nm 程度であるのに対し， $\mathrm{VC}$ のすべり面上での間隔は $30 \sim 50 \mathrm{~nm}$ 程度で，ラメラ間隔 の1/3 1/4程度だった。したがって，もしもパーライトラ メラと VCが転位の移動に対する障害物としての作用が まったく同じであれば，パーライト中のフェライトへの $\mathrm{VC}$ の相界面析出により，ラメラによる強化は大幅に減少 すると考えられる。しかし実際には，ポリゴナルフェライ ト中とパーライト中の VCの析出強化能に大きな差はな かった。このようになる理由としては，式(1)の AshbyOrowanの式から推定されるように，析出物の大きさが強 化量に影響するので，VCに比べてラメラセメンタイトの 方が格段に大きく，強化に対する寄与が大きくあること， また形状も VCが粒状であるのに対し，ラメラセメンタイ 卜は板状であることが，転位の運動に対する障害物として 有効に作用すると推測される。以上のような理由から，今 回調査した範囲であれば，VC粒子が微細分散していても， パーライトラメラによる強化量はほとんど減少しないため に，見かけ上，VCによる析出強化とパーライトラメラに よる強化は単純加算できたと考えられる。

\section{5. まとめ}

（1） V 添加非調質鋼を高強度化するためには，V量を
増やすことと, パーライト主体の組織になる範囲内でより 低温で変態させることが有効である。C量を高めることは, より低温までべイナイト組織の形成を抑制してパーライト 主体の組織を得ることに有効で，それが高強度化に寄与す る。

（2）上記の知見に基づいて, $550^{\circ} \mathrm{C}$ 等温変態によって $65 \mathrm{C}-4 \mathrm{~V}$ 鋼で YS $1450 \mathrm{MPa} ， 65 \mathrm{C}-2 \mathrm{~V}$ 鋼で YS $1200 \mathrm{MPa}$ が得 られた。

（3） TEM観察結果から VC粒の定量化を行い，VCの直 径が 1 2 $\mathrm{nm}$ であっても析出強化機構は Cutting 機構ではな く, Orowan機構であること, 析出強化量の予測が AshbyOrowanタイプの式で可能であることを明らかにした。

（4）パーライトラメラによる強化と VCによる析出強 化は競合する可能性があるが，見かけ上，ポリゴナルフェ ライト中と，パーライト中のフェライトに相界面析出した $\mathrm{VC}$ の析出強化能は同等である。

本研究を考察するにあたり，東北大学金属材料研究所 教授 古原 忠博士，助教 宮本吾郎博士から有益なアト バイスをいただきました。また本研究は，新エネルギー・ 産業技術総合開発機構(NEDO)からの助成事業により実施 する「鉄鋼材料の革新的高強度・高機能化基盤研究開発研 究体」の研究成果であることを記し，謝辞を表す。

\section{文献}

$1)$ H.Kojima: CAMP-ISIJ, 5 (1992), 772.

2 ) S.Niwa, I.Machida, T.Katoh, N.Uehara and Y.Tanaka: Denki Seiko (Electr. Furn. Steel), 53 (1982), 26.

3 ) I.Nomura, T.Katoh, Y.Hanai and T.Yamamoto: CAMP-ISIJ, 5 (1992), 789.

4 ) N.Iwama, I.Nomura, M.Mori, M.Yano and T.Manabe: Materia Jpn., 36 (1997), 622.

5 ) S.Ito, H.Yoshida and S.Isogawa: Proc. 2004 Jpn. Spring Conf. for the Technol. of Plast., (2004), 357.

6 ) S.A.Parsons and D.V.Edmonds: Mater. Sci. Technol., 3 (1987), 894

7 ) A.T.Davenport and R.W.K.Honeycombe: Proc. Roy. Soc. London, 322 (1971), 191.

8 ) T.Suzuki and Y.Mishima: Denki Seiko (Electr. Furn. Steel), 55 (1984), 131.

9 ) R.Hori, B.Poorganji, G.Miyamoto and T.Furuhara: CAMP-ISIJ, 2 (2008), 1367, CD-ROM.

10) T.Gladman: Phys. Metall. Microalloyed Steels, The Inst. of Mater. London, (1997), 52.

11) K.Yamada, K.Sato and H.Nakamichi: JFE Tech. Rep., 13 (2006), 18.

12) W.Heller: Rail Steels, STP 644 ASTM, Philadelphia, (1979), 162.

13) A.R.Marder and B.L.Bramfitt: Metall. Trans. A, 7A (1976), 365. 